\title{
Demanding Relations: Sociological Imagination, Education, the Usefulness of Concepts and the World Around Us
}

\author{
Živa Kos \\ Veronika Tašner \\ University of Ljubljana. Slovenia. \\ ziva.kos@guest.arnes.si \\ veronika.tasner@pef.uni-lj.si
}

Received: 29/10/2019

Accepted: 25/3/2020

Published: 29/1/2021

\begin{abstract}
The present paper draws on fostering sociological imagination (Wright Mills, 2000) and contemporary possibilities in teaching and learning sociological concepts in relation to education. The authors present a method of reading films as a didactic tool in connection to selected sociological texts in order to better understand theory and praxis in the educational field and beyond. The film Billy Elliot was chosen as a didactic tool for presenting how Bourdieu's concepts of habitus and forms of capital, as well as Bernstein's conceptualisations of language codes, can be used in the pedagogical process. Emphasis is placed on education and the ways in which it contributes to shifting or reproducing social inequalities, class inequalities and gender.
\end{abstract}

Palabras clave: habitus; forms of capital; language; codes; teaching and learning; sociology

Resum. Relacions exigents: la imaginació sociologica, l'educació, la utilitat dels conceptes i el món que ens envolta

El present treball es basa en els fonaments de la imaginació sociològica (Wright Mills, 2000) i en les possibilitats contemporànies d'ensenyar i aprendre conceptes sociològics en relació amb l'educació. Els autors presenten un mètode de lectura de pel.lícules com a eina didàctica en relació amb textos sociològics seleccionats per entendre millor la teoria i la praxi en l'àmbit educatiu i més enllà. La pel-lícula Billy Elliot va ser escollida com a eina didàctica per presentar com es poden utilitzar en el procés pedagògic els conceptes d'habitus i les formes de capital de Bourdieu, així com les conceptualitzacions de Bernstein dels codis lingüístics. Es posa l'èmfasi en l'educació i les formes que contribueixen a canviar o reproduir les desigualtats socials, les desigualtats de classe i el gènere.

Paraules clau: habitus; formes de capital; llengua; codis; ensenyament i aprenentatge; sociologia 
Resumen. Relaciones exigentes: la imaginación sociológica, la educación, la utilidad de los conceptos y el mundo que nos rodea

El presente trabajo se basa en el fomento de la imaginación sociológica (Wright Mills, 2000) y las posibilidades contemporáneas en la enseñanza y el aprendizaje de conceptos sociológicos en relación con la educación. Los autores presentan un método para entender las películas como una herramienta didáctica en conexión con textos sociológicos seleccionados para comprender mejor la teoría y la praxis en el campo educativo y más allá. La película Billy Elliot fue elegida como una herramienta didáctica para presentar cómo los conceptos de habitus y formas de capital de Bourdieu, así como las conceptualizaciones de Bernstein de los códigos del lenguaje, pueden usarse en el proceso pedagógico. Se hace hincapié en la educación y las formas que contribuyen a cambiar o reproducir las desigualdades sociales, las desigualdades de clase y el género.

Palabras clave: habitus; formas de capital; lenguaje; códigos; enseñanza y aprendizaje; sociología
Summary
1. Introduction
4. Conclusion
2. On film, reading and learning: methodology
Bibliographical references

3. Billy's story and the milieu

\section{Introduction}

As indicated by Wright Mills (2000), sociological imagination is always a reflection of the time and environment, and of the need to understand events in the world and what is happening to "us". According to the author, understanding the culture, cultural patterns and values of a certain society is therefore always related to understanding the social sciences. Critics of modern society and school highlight the risks of instrumentality and the subsequent emphasis on applicable knowledge (Biesta, 2010) rather than quality of thought (Wright Mills, 2000). Traces of this can be found in conceptualisations and praxes of learning and teaching, in seeking suitable approaches (whether more or less productive), innovative methods, etc. (Trippestad, Swennen, \& Werler, 2017). It is important for teachers to know the possibilities and limitations of various conditionings, whether of our own knowledge or of the rationality of the population entering school (Bourdieu \& Passeron, 1990; Bernstein, 2003).

Bauman's thesis on the modern form of individualism and consumer society (2002) can be used to try to understand the rationality of the population. The generations now entering school do not know a world without digital media. The power of the effortlessness, fun and density of information that directly or indirectly structures young people's grasp of the world and themselves offers sociology teachers anchors for reflection on and shifts in indisput- 
able truths, not only in working with pupils but also with regard to themselves (Dewey, 1997; Wright Mills, 2000) and therefore puts forth the possibilities of using sociological knowledge to inform educational practice.

The present paper should therefore be read as an attempt to shift that which arises as the dominant rationality of the contemporary sociological imagination and the "applicability" of sociological knowledge in teaching and learning. ${ }^{1}$ The first part introduces the possibilities of using films as media for teaching and learning. The possibilities of using different approaches is outlined and narrowed to the selected conceptual apparatuses of Bourdieu (habitus, forms of capital) and Bernstein (language codes, class inequalities). The second part presents the possibilities of using these concepts in the reading of and learning from the film Billy Elliot.

\section{On film, reading and learning: methodology}

Although films - moving pictures - are most often watched and understood primarily as a source of entertainment, Jacques Derrida believes they can also be read (Agger, 1992). Reading films enables people to (better) understand and analyse them, and encourages creativity and innovation in using new or previously acquired knowledge. At the same time, this approach allows us to go beyond "liking or disliking" a film (Rutar, 2005, p. 62). Reading allows for a different, deeper understanding of a film, and enables the viewer to combine his or her understanding and usage of scientific approaches and concepts with entertainment and joy. Even when films are read, they do not lose their component of entertainment and fun. Various methods are used to analyse films, with psychoanalysis being the most common, although other approaches, amongst them sociological, have emerged over the past decades, as well (Sutherland \& Feltey, 2012; Allen, 2004) We know of feminist film theory, structuralism, post-theory, neo-formalism, cognitivism, etc. In order to use these, however, we must nurture a perspective that allows us to learn from films and obtain new meanings from moving pictures.

In this case study of film analysis, we will use Bourdieu's and partly also Bernstein's construction of the studied object and select a certain number of traits of film that allow for a relatively clear link between concepts from theory and a relatively fluid film story (Bourdieu \& Wacquant, 1996). We believe that this method of reading the selected film allows us to explain the fundamental sociological concept of inequality and school, and to understand the

1. The method presented in this paper was inspired through teaching Sociology of Education at the Faculty of Education, University of Ljubljana. The aim of the approach was to introduce the applicability of sociological concepts to everyday practices. Students were first introduced to theoretical concepts by studying selected writings (Bourdieu, Bernstein, etc.) and afterword asked to deconstruct the selected film using those concepts. The aim of using this method was to minimize the gap between theory and practical use of sociology and also to foster sociological imagination in relation to cultural and media production in contemporary society. 
structure of the world, individual fields and the positioning of individuals in it through the concepts of the authors referred to.

At this point, we will focus on Bourdieu's conceptualisation of the forms of capital (Bourdieu, 1986) (where they can be found in the film, who the holders of various forms of capital are); on habitus (the case of the classification of gender roles and in parts of social classes); on social practices; and on Bernstein's concept of formal and informal language or elaborated and restricted codes. Together, these concepts enable a better insight into understanding the reproduction of social and educational relations, offering a specifically sociological perspective on the process of education and above all on the socially conditioned methods of learning and teaching the formation of social (gender) roles, as well as on the reproduction of social relations.

The selection of the film for reading must be performed just as carefully as the selection of a suitable text for reading and analysing a selected social phenomenon. If we want to explain theoretical concepts such as habitus, forms of capital and related structures and practices, etc. - as well as using the case to pinpoint issues that arise from using restricted and elaborated language codes in schools, following through all the way to explaining social inequality and the classification of gender roles - the choice is rather limited. To study all of the above, in this paper we have selected Billy Elliot, a film about a working-class boy who chooses ballet instead of boxing.

\section{Billy's story and the milieu}

The British coal miners' strikes of the mid 1980s, when Margaret Thatcher was introducing neoliberalism and trying to eliminate "the welfare state" in the United Kingdom, provided the backdrop for the film. The protagonist, Billy Elliot, is an eleven-year-old who lives in a typical mining community with his widowed father, his older brother and his maternal grandmother, who has Alzheimer's disease. The father and the brother, both miners, spend most of their time working to support the family at a time when the mining community is on strike and negotiating with the British government. This gives the youngest Elliot plenty of time to care for his grandmother and, above all, plenty of time to himself. His father is trying to raise him to be a "real" man and, despite a lack of money, enrols him in boxing classes, which are part of the family tradition (both his father and grandfather were boxers). The story is set up by the fact that Billy is not very good at boxing and is not interested in the sport. Moreover, his physique, which in no way resembles that of a typical British miner, is unsuitable for boxing. When the strike causes the local girls to lose their venue for ballet classes, resulting in them joining the boys in the gym, the second condition for the plot is established. Subsequently, a turn of events leads to Billy joining ballet classes instead of boxing classes - and when Billy dances, concepts start dancing too. 


\subsection{The Elliots and forms of capital}

The first of the concepts that can be explained against the backdrop of the social circumstances of the Elliots and the family of ballet teacher Mrs Wilkinson is the concept of Bourdieu's forms of capital. Bourdieu (1986) explains the concept of capital as:

accumulated labor (in its materialized form or its "incorporated," embodied form) which, when appropriated on a private, i.e., exclusive, basis by agents or groups of agents, enables them to appropriate social energy in the form of reified or living labor. It is a vis insita, a force inscribed in objective or subjective structures, but it is also a lex insita, the principle underlying the immanent regularities of the social world. It is what makes the games of society-not least, the economic game-something other than simple games of chance offering at every moment the possibility of a miracle. (p. 15)

Understanding the individual's starting points within the social environment is important for understanding his or her circumstances and conditionings while growing up, and for grasping their importance for the individual's future life. Imagining the social environment as proposed by Leskošek and Dragoš (2003) prompts the realisation that the positions of individuals within a society are differently equipped with individual forms of capital (economic, cultural, social); that these positions move in different directions and with different speeds; and, above all, that starting points in the positions' game are importantly dependent on the individual's starting point, that is, where the individual entered the social environment through primary socialisation. It is primary socialisation that is importantly, or even decisively, determined by the social status of the family (p. 45) in which the individual grows up.

Comparing the living conditions of the first (Elliot) family and the second (Wilkinson) family allows us to analyse the best-known form of capital: economic capital. The workers' community is full of small houses with outhouses and small, simply equipped rooms, with laundry drying under the kitchen ceiling. This all speaks of the low economic status of the Elliots. By comparison, the suburban district of the Wilkinsons is full of larger houses with carefully trimmed lawns and cars in the driveways, which speaks of the higher economic and social standing of the teacher's family. The difference in status can easily be found in everyday things that point to the families' tastes, including the food each family consumes and the furniture and decor in the rooms, as well as the bedding used by Debbie and Billy, the children of the two families.

In addition to the differences in economic capital, the families also have different cultural capital, which, being "investment of time and effort", is not uniform. Cultural capital can be seen in the embodied state that represents the lasting dispositions of an organism. We can perceive this in the ballet teacher, who is relatively refined, has some dance cultural capital and is trained as a teacher. She soon recognises Billy's potential in dance and knows how to encourage him to develop this potential. She has certain proficiencies and skills 
that count for more than others in certain fields: they have greater value and are recognised in society, and can thus be interpreted as forms of cultural capital. At the end of the film, Billy also gains some cultural capital when he appears in the lead in Swan Lake. At this point, it is worth pointing out the difference between Billy's potential at the beginning of his path, when traces of his talent for expressing himself through movement can be perceived, and the proficiency and skill he obtains during his dance training, culminating at the end, when his dance cultural capital has a certain value: people appreciate him, they come to the theatre and the opera house recognising him as someone worth seeing and acknowledging his skills as something that not everybody can possess. There are not many who can take the lead role in such a venue. At the end of his training, Billy obtains another form of cultural capital: the institutional form. This form of cultural capital is most often found in the form of a certificate obtained when successfully concluding formal education. The ballet teacher and members of the admissions committee at London's Royal School of Ballet also have the institutional form of cultural capital.

Presenting forms of capital, Bourdieu says that cultural capital can be found in an objectified state (Bourdieu, 1986). For the Elliots, a materialised form of cultural capital is represented by the mother's piano and the framed photographs on it, as well as by her jewellery. On the other hand, the family's boxing gloves, passed down through generations, represent this form of capital for the Elliot men.

The character of the teacher can help explain the third form of capital: social capital. This is represented by a relatively permanent network of relationships and ties between the individuals of a certain group; it is the entirety of these contacts, relations, acquaintances, friendships and duties. Although often equated with connections and acquaintances, there is in fact an important difference. Social capital carries social profit through belonging to a certain group - for instance, the teachers' group - and is not based exclusively on personal acquaintances between agents in a certain field. This can be discerned in the ballet teacher's written recommendation of Billy addressed to the members of the auditions commission. Agents of a certain field - in this case the ballet community - may not know each other personally, but nonetheless recognise each other as members of a certain group with certain competences. Social capital often exists as the potential that holders try to institutionalise. According to Bourdieu (1986):

Social capital is the aggregate of the actual or potential resources which are linked to possession of a durable network of more or less institutionalized relationships of mutual acquaintance and recognition —or in other words, to membership in a group - which provides each of its members with the backing of the collectively owned capital, a "credential" which entitles them to credit, in the various senses of the word. These relationships may exist only in the practical state, in material and/or symbolic exchanges which help to maintain them. They may also be socially instituted and guaranteed by the 
application of a common name (the name of a family, a class, or a tribe or of a school, a party, etc.) and by a whole set of instituting acts designed simultaneously to form and inform those who undergo them. (p. 21)

As an art form, ballet also carries a dimension of symbolic capital that Bourdieu defines as "the form that the various species of capital assume when they are perceived and recognized as legitimate" (1989, p. 17, 1986). Symbolic capital is connected to reputation and is based on the relations between the three primary forms of capital (economic, cultural and social). Thus, education is not "only" cultural capital; obtaining a degree from a recognised institution - the Royal School of Ballet in our case - also carries symbolic capital. Prestigious institutions ensure symbolic value that usually strengthens social capital in a certain field - in ballet circles in our case - in relation to the aforementioned conversions of capital, while also having an impact on the accumulation of economic capital (the number of appearances in shows and the fees achievable). In the film, Billy's father eventually also recognises the symbolic dimension of ballet education. When he sees Billy dance for the first time, he realises that his son has an opportunity to live his life beyond the streets of the mining town, as the boy has an unexpected talent. In order to make it possible for Billy to travel to London for the ballet audition despite the difficult economic situation, which is made even worse by the strike, Billy's father is willing to break his commitment to the mining community. This is another interesting aspect of social and symbolic capital. The father is willing to become a strike-breaker and go into the mineshaft for meagre pay. In the end, his older son, a union leader, prevents him from doing so by promising the father that they will find another way to get the required money.

\subsection{Linguistic capital as cultural and symbolic capital}

In addition to possessing different forms of capital, the worlds of the Elliots and the teacher's family are differentiated by the language they use. Using Bernstein's $(1961,2003)$ theory of elaborated and restricted codes and public and formal language, we can see that the Elliots, members of the lower working class, speak public language and use restricted language codes, whereas the teacher and her family speak formal language and use elaborated codes, the language of the middle class. Language and linguistic capital, as Bernstein (1961, 2003) showed, strengthens the social position of individuals in society and limits their opportunities especially in accumulation of cultural capital and schooling. We will try to put forth some of the elements of the abovementioned reproduction (Bourdieu \& Passeron, 1990).

This is important because Bernstein says that forms of spoken language are those that lure, strengthen and generalise special forms of relations to the environment and thus form certain dimensions of meanings in the process of learning. Regarding language differences, he claims that "grossly different environments affect aspects of language structure and vocabulary" (Bernstein, 
1961, p. 291). This is nicely depicted in the dance audition, when Billy has trouble communicating with a middle-class boy in the locker room and finds it difficult to verbally communicate the feelings he has when dancing. His father is also very sparing in his answers to the audition commission, and does not ask them any questions. Even when Billy is angry, rather than verbalising his feelings, he dances - more aggressively than usual - or turns to violence: he hits the boy who is empathic and tries to console him after Billy fails to put on his best performance in the audition.

Examining this context and remembering that school is the one institution in which the dominant language mode is that of the middle class (Bernstein, 1961) reaffirms Bourdieu and Passeron's old thesis about school being the mechanism that reproduces social inequalities. Middle-class children are formed within a "formally articulated structure" (Bernstein, 1961, p. 292); their behaviour is modified and oriented towards "an explicit set of goals and values" (Bernstein, 1961, p. 292). This is clearly evident in the case of Billy's friend Debbie, the daughter of the dance teacher, who grows up within a more or less orderly rational structure, in which her entire experience is organised from an early age. The goal in middle-class families is "efficacy in attaining distant ends" (Bernstein, 1961, p. 292). Within the middle class, "direct expressions of feeling, in particular feelings of hostility, are discouraged" (Bernstein, 1961, p. 292). Bernstein stresses that, in differentiating between a middleclass and a working-class child, we are dealing above all with the difference in the way they express themselves, not "necessarily the size of the vocabulary" (Bernstein, 1961, p. 292). This can be perceived in dialogues between Billy and Debbie. Billy, a working-class child who speaks public language, must translate middle-class sentences in order to give them meaning; if he cannot undertake this "translation he fails to understand and is left puzzled" (Bernstein, 1961, p. 293). The example of a dialogue between the teacher and Billy about attending the audition uses the trick of double entendre, but it is clear that they each speak their own language, despite the fact that the teacher is also capable of using Billy's language, that is, public language.

Language - the spoken word - Bernstein shows $(1961,2003)$ is what denotes the patterns of stimuli that children recognise; in learning these patterns, their perception and structuring is organised. The way they were socialised is revealed every time they speak. An example is Billy's revolt against the teacher when he can no longer dance: she raises her voice to demand focus, because this is the code that the boy understands. In this example, she does not act as she would with her daughter, as a middle-class mother who counts on "recollected guilt" in addressing a child. In order to establish such a relationship, a process of individualisation is required, which presupposes: consistent monitoring of a child by his/her parents; being attentive to new forms of behaviour and comments (reaction to action); and a reaction that includes recognition and rejection of actions (communicated to the child, of course). Billy, a working-class child, has had none of these. 


\subsection{Habitus - the individual and the collective}

In addition to explaining the concept of capitals, the life of the Elliots also presents an opportunity to demonstrate the concept of habitus, "a structured and structuring structure produced through conditionings connected to the special class of the circumstance of existence" (Bourdieu, 2002, p. 90). Bourdieu (1992) defines habitus as follows:

the conditionings associated with a particular class of conditions of existence produce habitus, systems of durable, transposable dispositions, structured structures predisposed to function as structuring structures, that is, as principles which generate and organize practices and representations that can be objectively adapted to the outcomes without presupposing a conscious aiming at ends or an express mastery of the operations necessary in order to attain them. Objectively 'regulated' and 'regular' without being in any way the product of obedience to rules, they can be collectively orchestrated without being the product of the organizing action of a conductor. (p. 53)

Thus habitus conditions our perception and recognition, as well as our motivations and aspirations. Our desires hit habitus. It is the way people understand objective social structures. It works as the practical sense of the game. The practical world is in some way the result of the meeting of habitus and event(s). Some forms of habitus are better known, familiar and part of our practices, while others are new and unknown, sometimes even repelling us and inciting fear. The film shows several situations in which Billy and his family hit the limits of the working-class habitus and social gender. It is represented as discomfort, withdrawal or resistance, and is at times seen as defence against the unknown, even through outbursts of violence.

The practical world is established in the attitude towards habitus, towards structures that work as a system of cognitive and motivating structures and function on the axis of "what is and what is not for me, for us". Habitus, says Bourdieu (1992), is:

a product of history, [it] produces individual and collective practices - more history - in accordance with the schemes generated by history. It ensures the active presence of past experiences, which, deposited in each organism in the form of schemes of perception, thought and action, tend to guarantee the 'correctness' of practices and their constancy over time, more reliably than all formal rules and explicit norms. (p. 54).

This is visible in the habitus of each individual Elliot. The father, whose actions are determined by the fact that he is a man - the man of the house and a miner whose work is manual and arduous - and by the fact that "he has not been beyond the limits of his town". The older brother follows in his father's footsteps and mostly follows the practices of his ancestors. His habitus, too, is established based on the class of existential circumstances, conditions and conditionings. At this point, let us again quote Bourdieu (1992), who says: 
If a very close correlation is regularly observed between the scientifically constructed objective probabilities (for example, the chances of access to a particular good) and agents' subjective aspirations ('motivations' and 'needs'), this is not because agents consciously adjust their aspirations to an exact evaluation of their chances of success, like a gambler organizing his stakes on the basis of perfect information about his chances of winning. In reality, the dispositions durably inculcated by the possibilities and impossibilities, freedoms and necessities, opportunities and prohibitions inscribed in the objective conditions (which science apprehends through statistical regularities such as the probabilities objectively attached to a group or class) generate dispositions objectively compatible with these conditions and in a sense pre-adapted to their demands. (p. 54).

On the other hand, Billy indicates that he is seeking his own path by resisting his father; habitus also produces individual practices. The disposition of habitus (habits, ways of doing things, understanding the world, feelings), the obtained generative schemes "allow free production of thoughts, perceptions and all the actions inscribed in the limits (...) but only those" (Bourdieu, 1992 , p. 54). The miners' world of the father is also the sons' world. In addition to individual habitus, the viewer can find collective - class - habitus in the film: the habitus of miners, the habitus of the lower working class. Class habitus is the product of the same and similar existential conditions and conditionings, while at the same time being a class of biological individuals who have the same habitus as the system of dispositions that are common to all products of the same conditionings.

The concept of habitus denotes "conditioned and conditional freedoms" (Bourdieu, 1992, p. 54), but the case of Billy can be used to show that Bourdieu cannot be proclaimed as deterministic because of the concept of habitus. Billy, the son of a miner and boxer, is not predestined by definition to become a miner and boxer. He is, however, limited in his actions and choices by the conditionings that he was exposed to in his earliest socialisation. We presume that the mother - like most women, according to Bourdieu - was the main transmitter of cultural capital in the Elliot family and played the crucial role in Billy's conditionings.

The genesis of a system of works or practices generated by the same habitus (or homologous habitus, such as those that underlie the unity of the lifestyle of a group or a class) cannot be described either as the autonomous development of a unique and always self-identical essence, or as a continuous creation of novelty, because it arises from the necessary yet unpredictable confrontation between the habitus and an event that can exercise a pertinent incitement on the habitus only if the latter snatches it from the contingency of the accidental and constitutes it as a problem by applying to It the very principles of its solution. (1992, p. 55)

An event can, according to the author, only challenge habitus suitably if it removes it from the contingency of coincidence and establishes it as a problem 
(Bourdieu, 1992, p. 55). Ballet can only challenge habitus if habitus (insofar as it can or wants to) notices it. Although initially only unwillingly and with difficulty, Billy's habitus does this in the end. Despite the fact that Billy has no skill in ballet (he obtains it through training and reading a "borrowed" book about ballet, which can be thematised as a set of conditionings different from those to which Billy was exposed in the family), his habitus eventually reacts to ballet. He is no longer unskilled, he is not embarrassed, and he does not fight it anymore; he feels better on the dance floor than in the boxing ring. Habitus always tries to formulate all possible answers (within its limits) to an event. At the same time, it tries to eliminate all eccentricities that are incompatible with "objective circumstances": they fall outside the reach of habitus. In such cases, people are embarrassed, they blush, look away, fall silent, etc. Billy also encounters such "eliminations" when he has to decide for or against ballet. At the beginning, he is quite certain that ballet is not suitable for a real man, and his friend Debbie has to convince him of the opposite. For the purpose of the present paper, this scene (as well as several others) leads us to a discussion of the classification of gender roles.

\subsection{Men box, women do ballet}

The concept of habitus allows us to thematise the question of why Billy believes that men box and women do ballet. ${ }^{2}$ In Masculine Domination (2001), Bourdieu finds social practices, practices of classification. These are practices that are ordered and structured with regard to the system of classifications. The system linked to gender is among the most important of these. It seems as though differences between genders originate in the "nature of things" (Bourdieu, 2001, p. 8). Just like other forms of symbolic order, gender classification with the male/female dichotomy is also present in objects (objectified state), such as in the home, where spaces are strictly determined as either male or female; it is the same in society and in agents' habitus (embodied state). This is embodied in habitus and functions as a "system of schemes of perception, thought and action" (Bourdieu, 2001, p. 8). We can also perceive it in the division of labour between genders, as noted previously by Bourdieu in Logic of Practice (1992). In describing the division of labour, Bourdieu thoroughly describes male and female jobs and notes three main oppositions: the opposition between moving within and moving outwards, the opposition between wet and dry, and the opposition between uninterrupted actions and short, interrupted actions. At another point, he states that knowing the fundamental principle of division (his pattern is the opposition between the sexes) allows for "a new design, and therefore complete understanding of all rituals and symbolic practices" (1992, p. 68-77).

2. For the purpose of this paper, we will use the binary division of genders, although we are aware that there are more genders and that, in describing gender order, the non-binary perspective must be considered. 
In addition to social practices acting through the symbolic order, the symbolic order of gender is embodied in individual habitus as gender perceptions of the world. The gender-specific habitus "internalises and embodies the gender division of labour" (Karis, 2006, p. 121). This allows us to speak of female or male habitus that takes on a personal form and forms every individual from their very beginnings. Gender-specific habitus is among the "central elements of an individual's identity" (Karis, 2006, p. 121). It determines the individual's self: it is perceivable as "pure nature", as the body. Bourdieu claims that the symbolic order of gender is the social programme of perceptions that constructs the body as a biological reality. The very social construction of femininity or masculinity is that which defines the body, defines how it is understood and perceived, how it forms physical habits (holding of hands or legs, lowering of eyes, etc.) and means of expression, thus determining the individual - through their body - as male or female. This is why, for Bourdieu, male domination is nothing but "the embodiment of social relations of domination" (2001, p. 23), perceived as normal and natural.

Bodily hexis is political mythology realized, em-bodied, turned into permanent disposition, a durable way of standing, speaking, walking, and thereby of feeling and thinking. The opposition between male and female is realized in posture, in the gestures and movements of the body, in the form of the opposition between the straight and the bent, between firmness, uprightness and directness. (Bourdieu, 1992, p. 68-69)

The pretence that this is the natural order of the world is what pushes us more than anything else into forgetting that the social structure itself is produced and reproduced by people.

The thing that is interesting in Bourdieu's gender order, originating from the gender typology of the body (bodily hexis), is the shift away from Freud. Bourdieu claims that:

phallus is not the foundation of the perception of the world, but a perception of the world can make phallus the symbol of masculinity from the aspect of typical male honour because it is ordered based on the division of relations between genders, male and female. (2001, p. 22)

Therefore, only when differentiation between male and female is established are men attributed with virtue (vir, virtus), honour, thus assigning greater value to all male attributes. Female virtues are completely different; their honour originates in restraint, passivity, inaccessibility, "purity", etc. It is through this differentiation that the superiority of men over women is established. As such, it does not need any kind of vindication, because men, those who dominate, "have no need for vindication: male-centred perception is understood as neutral... social progress works as a big symbolic machine, whose goal is to confirm male domination it is based on: the gender division of labour" (Bourdieu, 2001, p. 17). As he states, the main agents of the social 
reproduction of gender order are family, church, education system and state. It is thus not surprising that the Elliots believe that ballet is not suitable for men. They are not alone in their belief, but by the end of the film they succeed in changing it.

\section{Conclusion}

We have based our deliberations about learning and teaching on the belief that it is not advisable to forget theory and reading in seeking new innovative approaches to learning and teaching. The authors' experience is that both ${ }^{3}$ are required in order to understand concepts.

Bourdieu and Bernstein and others (e.g. Dewey, 1997) highlight the importance of experience and suitable environments in conditioning the individual, emphasising the ensuing inequalities. Sociological imagination as the cultivation of thoughts and social and individual practices is becoming a necessity in modern society. Finding ways to coexist in the increasing complexity of social relationships points to the rationality of thinking and to the necessity of understanding the importance of experience that goes beyond the directness of the imposing immediateness of reality. Discovering and recognising worlds and experiences different from those we consider self-evident is a part of sociological imagination that is and will be necessary for the safe coexistence of social and individual diversity, as in the case of multiple discourses regarding gender identities and gender inequalities in the last decades (Connell, 1995; Reed, 2006; Ivinson \& Murphy, 2006; Ahmed, 2006; Perger, 2014).

Art, whether literature, as referred to by Wright Mills (2000), or film, offers a view of social relations, a diversity of human realities that allows for the sensitisation of individuals in the field of education through the use of sociological theories and concepts. Wright Mills finds the cultivation of humanistic culture especially important because the dominating social imagination forgets that technical/technological experience is not the same as human experience.

The present paper is therefore an attempt to demonstrate how both sociological theory and different readings can be used in a different, socially and didactically innovative and yet effective way "that sticks". The described approach allows for the description and appropriation of certain basic concepts of selected sociologists of education, such as habitus, capitals and language codes. These can be seen "in practice" and thus better understood through the analysis of a film.

3. The described approach has been used and upgraded several times with different groups of students of the Faculty of Education, University of Ljubljana. 


\section{Bibliographical references}

Ahmed, S. (2006). Queer phenomenology: Orientations, objects, other. London: Duke University Press.

Agger, B. (1992). Cultural studies as critical theory. London: Falmer Press.

Allen, R. (2004). Psychoanalitic film theory. In T. Miller \& R. Stam (Eds.). A companion to film theory (pp. 123-145). London: Blackwell Publishing Ltd.

Bauman, Z. (2002). Tekoča moderna. Ljubljana: Cf.

Biesta, G. (2010). Good education in an age of measurement. London: Paradigm Publishers.

Bernstein, B. (1961). Social class and linguistic development: A theory of social learning in education. In A. H. Halsey, J. Flouds \& C. A. Anderson (Eds.). Economy and Society (pp. 288-314). New York: Free Press.

- (2003). Theoretical studies towards a sociology of science. Class, codes and control: Vol.1. London: Routledge \& Kegan Paul.

Bourdieu, P. (1986). The forms of capital. In J. G. Richardson (Ed.). Handbook of theory and research for the sociology of education (pp. 241-258). New York: Greenwood.

- (1989). Social space and symbolic power. Sociological Theory, 7(1), 14-25.

- (1992). The logic of practice. Stanford: Stanford University Press.

- (2001). Masculine domination. Cambridge: Polity Press.

- (2002). Praktični čut. Ljubljana: SH.

Bourdieu, P. \& Passeron, J. C. (1990). Reproduction in education, society and culture. London: Sage.

Bourdieu, P. \& Wacquant, L. J. D. (1996). An invitation to reflexive sociology. Cambridge: Polity Press.

Connell, R. (1995). Masculinities. Cambridge: Polity Press.

Dewey, J. (1997). Democracy and Education. New York: The Free Press.

Ivinson, G. \& Murphy, P. (2006). Boys don't write romance: The construction of knowledge and social gender identities in English classrooms. In M. АRnot \& M. Ghaill (Eds.). The RoutledgeFalmer Reader in Gender \& Education (pp. 163180). London: Routledge.

Krais, B. (2006). Gender, sociological theory and Bourdieu's sociology of practice. Theory, Culture \& Society, 23(6), 119-134.

LeskošEK, V. \& Dragoš, S. (2003). Družbena neenakost in socialni capital. Ljubljana: Mirovni inštitut.

Perger, N. (2014). Med queer teorijami, qeer politikami in gejevsko-lezbičnimi gibanji. Družboslovne razprave, 30(77), 71-89.

REED, R. L., (2006). Troubling boys and disturbing discourses in masculinity and schooling: A feminist exploration of current debates and interventions concerning boys and school. In M. Arnot \& M. Ghaill (Eds.). The RoutledgeFalmer Reader in Gender \& Education, (pp. 33-48). London: Routledge.

Rutar, D. (2005). Vzgoja za družino in vrednote: kako s pomočjo filmov bolje vzgajati otroke. Ljubljana: UMco.

Sutherland, J. \& Feltey, K. (Eds.) (2012). Cinematic sociology. London: Sage.

Trippestad, T. A., Swennen, A. \& Werler, T. (Eds.) (2017). The struggle for teacher education: International perspectives on governance and reforms. London: Bloomsbury.

Wright Mills, C. (2000). The sociological imagination. Oxford: Oxford University Press. 